\title{
Article \\ Software for Evaluating Pumping Tests on Real Wells
}

\author{
Václav Ficaj (D, Pavel Pech *(i) and Daniel Kahuda \\ Faculty of Environmental Sciences, Czech University of Life Sciences Prague, Kamýcká 129, \\ 16500 Prague-Suchdol, Czech Republic; ficaj@fzp.czu.cz (V.F.); kahuda@fzp.czu.cz (D.K.) \\ * Correspondence: pech@fzp.czu.cz; Tel.: +420-724-077-070
}

check for updates

Citation: Ficaj, V.; Pech, P.; Kahuda, D. Software for Evaluating Pumping Tests on Real Wells. Appl. Sci. 2021, 11, 3182. https://doi.org/10.3390/ app11073182

Academic Editors: Nir Krakauer and Francesco Fiorillo

Received: 19 January 2021

Accepted: 31 March 2021

Published: 2 April 2021

Publisher's Note: MDPI stays neutral with regard to jurisdictional claims in published maps and institutional affiliations.

Copyright: (c) 2021 by the authors. Licensee MDPI, Basel, Switzerland. This article is an open access article distributed under the terms and conditions of the Creative Commons Attribution (CC BY) license (https:// creativecommons.org/licenses/by/ $4.0 /)$.

\begin{abstract}
As the climate is changing, greater exploitation of groundwater reserves is becoming evident; however, this would have been apparent even without climate change. Therefore, increasing emphasis is given to maintaining well functionality. Wells are susceptible to aging, which reduces their efficiency. Today, there exist several solutions for determining the size of additional resistance (the skin effect), which indicates a well's current state and that of its close surroundings. The implementation of most of these solutions is often time-consuming. To improve our tools, a goal has been set to accelerate and facilitate the method of determining the size of additional resistance. In this study, we present new software that accelerates this process. It applies an innovative method based upon a partial differential equation describing the radially symmetric flow to a real well, which occurs under an unsteady regime, using the Laplace transform. Stehfest algorithm 368 is used to invert the Laplace transform. Such software can be used to evaluate an additional-resistance well, even when a straight section evaluated using the Cooper-Jacob method is not achieved in the semilogarithmic plot of drawdown vs. log time during the pumping test. This solution is demonstrated in the comprehensive evaluation of 10 wells and 3 synthetic pumping tests.
\end{abstract}

Keywords: well; pumping test; additional resistances; skin factor; well aging; well regeneration; software

\section{Introduction}

Pumping tests are conducted for the purpose of determining not only aquifer parameters (hydraulic conductivity, transmissivity and storativity), but also well parameters (e.g., the coefficient of additional resistance, known as the skin factor, and well storage). In 1935, Theis [1], on the basis of idealized conditions, published a solution to a basic equation describing an unsteady, radially symmetric flow to an ideal well in a saturated aquifer. Theis used an analog equation describing thermal conduction in a solid environment to describe groundwater flow through a permeable environment [2]. His solution is used to determine an aquifer's transmissivity and storativity in the case of a well without additional resistances and with a negligibly small radius, and is known as the Theis type-curve method. Cooper and Jacob [3] built on this work by simplifying the Theis well function, generating a straight section for longer pumping test times when plotting drawdown vs. the logarithm of time and incorporating only the first two elements of the Theis well function, while omitting the others (the error in the calculations for the argument of the Theis function is less than $0.01-0.25 \%$ ). Pumping tests on actual wells are influenced first by additional resistances (expressed by the skin effect). Van Everdingen [4] and Hurst [5] were the first to incorporate additional resistances in a well and its close surroundings in calculations for oil wells. Hawkins [6] inserted additional resistances into calculations in the form of a zone around a well with altered hydraulic conductivity $(K)$. In the initial phase of a pumping (and drawdown) test, the well volume (well storage (WBS)) has a significant effect on drawdown over time. Papadopulos and Cooper [7] were the first to take this into account in underground hydraulics, while Ramey $[8]$ and others $[9,10]$ first incorporated this factor in the oil sector. Kucuk and Brigham [11] addressed the issue of the impact of a well's volume on pumping tests in elliptical coordinates. Mathias and Butler [12] 
expanded upon Kucuk and Brigham's solution by factoring in well storage and horizontal anisotropy. Yang et al. [13] and others [14,15] investigated this method in the Laplace domain. In 1970, Agarwal et al. [16] published a basic solution to the equation for unsteady, radially symmetric flow of a liquid to a complete well, taking into account additional resistances and the effect of well volume. Subsequent authors derived various approaches and methods, such as type curves, for determining additional resistances and well storage using a pumping test [17-23]. Van Everdingen [24] was among the first to use the Laplace transform to solve the basic partial differential equation for radially symmetric inflow into a well under an unsteady regime. Several authors from oil and groundwater hydraulics sectors $[22,23,25]$ have commonly applied solutions using the Laplace transform. Even to this day, Stehfest algorithm 368 [26] is often taken as the most suitable approach for inverting the Laplace transform in both groundwater hydraulics and the oil sector $[27,28]$. For example, several authors $[25,29,30]$ have applied the Stehfest algorithm to real wells (i.e., wells for which additional resistances and the effect of well volume are taken into account). Software applications are also currently used for real wells. This article elaborates a software solution for a real well, and the created software is used to evaluate the skin factor of 11 wells. The results are compared using the classic Cooper-Jacob method [3], which introduces a skin factor (application of the Cooper-Jacob method was possible because the pumping tests were sufficiently long for a so-called second straight section to be achieved in the semilogarithmic plot; Figure 1). An advantage of the presented software solution is the possibility of also using it in cases when no Cooper-Jacob straight section is achieved during the pumping test (i.e., for the early portion of pumping tests).

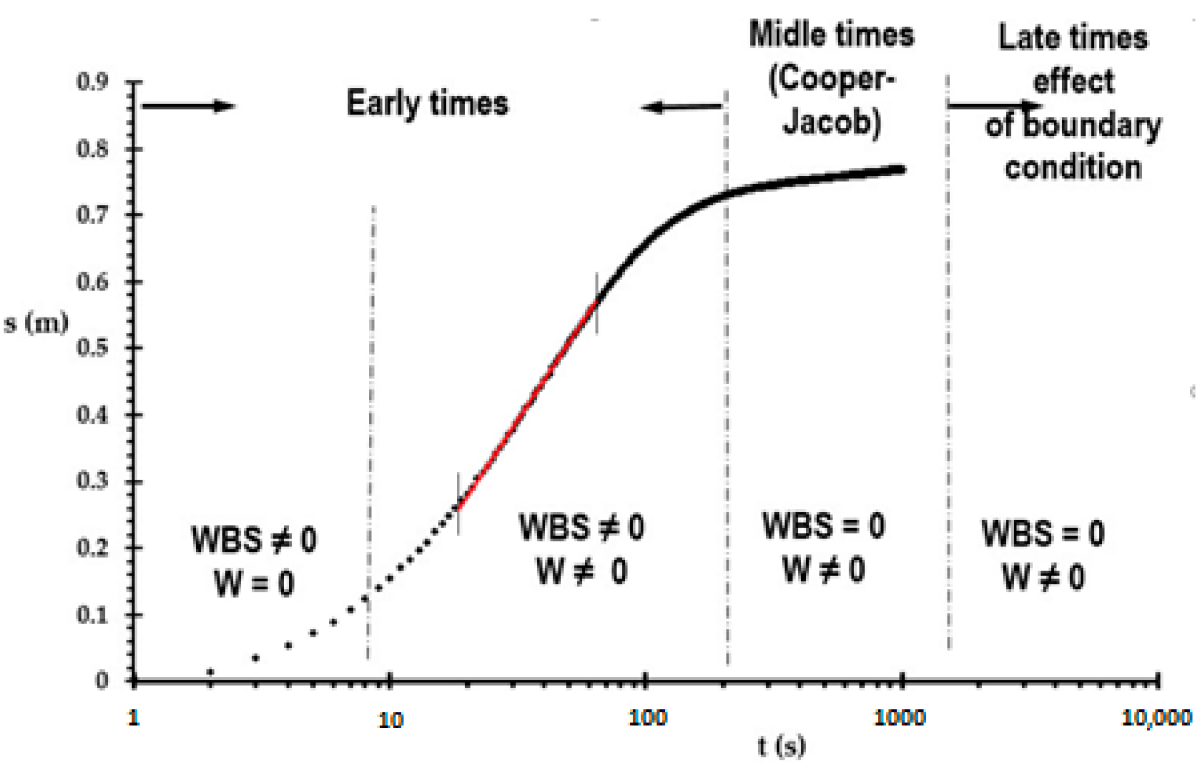

Figure 1. Semilogarithmic plot of drawdown s vs. $\log \mathrm{t}$ in a pumped well.

\section{Materials and Methods}

At present, pumping tests are most often used to determine aquifer parameters. To evaluate hydraulic parameters, it is essential to know the timing of water-level drawdown in the examined well and at least one observation well. In 1935, Theis [1] published a solution to the basic equation for radially symmetric flow to a well in a confined aquifer. The method of evaluating an aquifer's hydraulic parameters for an ideal well is known as the Theis type-curve method.

This method is seldom used in practice, because it is intended for an ideal well. Another method used to determine an aquifer's hydraulic parameters from pumping and build-up tests is the Cooper-Jacob semilogarithmic approximation [3]. This method is based on Theis' solution. For $1 / \mathrm{u}$ values of $>100$ with an error less than $0.25 \%$, the Theis well function can be simplified by leaving out its third and subsequent elements. This method 
is used for the straight-line section (red line), as seen in Figure 1, where the WBS represents well storativity and $\mathrm{W}$ represents the skin effect.

The final equation for drawdown in an ideal well is [3]

$$
s_{w}=\frac{Q}{4 \pi T} \ln \left(\frac{2.246 T t}{r_{w}^{2} S}\right)
$$

where $S_{W}$ is drawdown at a well $(\mathrm{m}), Q$ is the pumped amount of water $\left(\mathrm{m}^{3} \mathrm{~s}^{-1}\right), T$ is aquifer transmissivity $\left(\mathrm{m}^{2} \mathrm{~s}^{-1}\right), t$ is time (s), and $S$ is aquifer storativity (-).

\subsection{Additional Resistances (Skin Effect)}

Additional resistances cause most wells to lose their specific capacities over time. This results primarily from well aging due to mechanical, chemical, and biological processes. Mechanical degradation is most often caused by sedimentation of small particles in the well's close surroundings. Mechanical degradation may also occur when creating the well itself. All methods of well boring result in compacting and re-distributing material. Chemical degradation is most observed in areas where flowing water has higher amounts of dissolved mineral substances. This type of degradation is caused by deposition of mineral substances in individual sections of the well. The most common substances are calcium carbonate, magnesium carbonate, calcium sulfate, manganese, and iron. Biological degradation is caused by bacteria that occur naturally in most aquifer strata. These bacteria can be divided into three basic groups. The first and most widespread group consists of iron-oxidizing bacteria. These bacteria oxidize iron compounds and produce iron (III) hydroxide, an organic compound with a reddish color. This substance has a slimy character and forms deposits on well walls and pump parts and in the well's close surroundings. If the substance is exposed to wind, it hardens and can then cause even greater damage. The second group consists of sulfur-reducing bacteria. These bacteria can be found even in extremely acidic waters, with $\mathrm{pH}$ levels as low as 1 . These bacteria produce sulfuric acid and hydrogen sulfide. The presence of these bacteria may be indicated by a foul odor. The final group consists of slime-producing bacteria, which coexist with the aforementioned types of bacteria. The slime produced most often affects parts of the pump, but may also block the well screen or pores in the aquifer stratum around the well. All forms of well degradation described above alter the hydraulic conductivity of individual well parts and the adjacent aquifer stratum. The aggregate of all these factors is called the skin effect, a term first defined by van Everdingen. The term skin effect stems from the fact that these additional resistances can, in practical applications, be replaced by an infinitesimally thin zone (see Figure 2) that influences hydraulic conductivity. There are two types of skin effects: positive and negative. A negative skin effect is caused by the elevated permeability of the aquifer stratum in the well's surroundings. Elevated permeability occurs most often in environments featuring rifts. If individual rifts reach the well, a negative skin effect may occur. In practice, however, positive skin effects are more common. Such skin effects reduce the hydraulic conductivity in the near-well region [31-41].

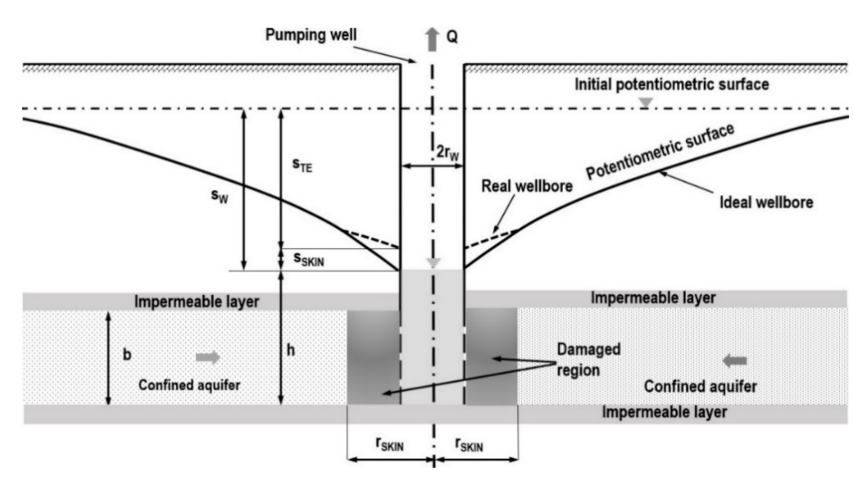

Figure 2. Diagram of a real well: an aquifer stratum with saturated water level. 
Based on [9], it is possible to calculate the coefficient of additional resistances, $W$ (skin factor), in the case of a real well, as in Equation (2).

$$
s_{w}=\frac{Q}{4 \pi T}\left(\ln \frac{2.246 T t}{r_{w}^{2} S}+2 W\right)
$$

where $W$ is the skin factor (-).

From Equation (2), the coefficient of additional resistances (skin factor) is

$$
W=\frac{2 \pi T s_{w}}{Q}-\frac{1}{2} \ln \frac{2.246 T t}{r_{w}^{2} S}
$$

and the drawdown caused by additional resistances (steady flow) is [4]

$$
s_{S K I N}=\frac{Q}{2 \pi T} W
$$

where $S_{\text {SKIN }}$ is the additional drawdown (caused by the skin effect) $(\mathrm{m})$.

\subsection{Well Storage (WBS)}

Well storage significantly impacts the initial phase of the pumping test (see Figure 1) in the order of seconds from commencing the test. The reason is that, at the start of the pumping test, water is pumped from the well itself. As the pumping test proceeds, inflow from the surrounding aquifer increases until it equals the pumped amount. The amount of water pumped from the well volume, on the other hand, decreases with time until it becomes negligible. The degree of this impact depends on the well radius. Ramey and Agarwal [8] addressed this issue and defined a per-unit well storage factor, as presented in Equation (5):

$$
C=Q \frac{t_{j}}{t_{j}},
$$

where $C$ is the per-unit well storage factor $\left(\mathrm{m}^{2}\right)$ and $t_{j}$ and $s_{j}$ are time and drawdown, respectively, from the unit slope log-log graph, where WBC dominates (Figure 1) [8].

This article uses the following dimensionless parameters (see $[16,42,43]$ ):

- Dimensionless time

$$
t_{D}=\frac{T t}{r_{w}^{2} S}
$$

- $\quad$ Dimensionless radius

$$
r_{D}=\frac{r}{r_{w}}
$$

- Dimensionless drawdown

$$
s_{D}\left(r_{D}, t_{D}\right)=\frac{2 \pi T}{Q}(H-h(r, t))
$$

- Dimensionless drawdown at a well

$$
s_{W D}\left(r_{D}=1, t_{D}\right)=\frac{2 \pi T}{Q}\left(H-h_{W}\left(r_{W}, t\right)\right)
$$

- Dimensionless well storage

$$
C_{D}=\frac{C}{2 \pi S r_{w}^{2}}
$$

where $r$ is the distance from the pumped well $(\mathrm{m}), H$ is the initial hydraulic head $(\mathrm{m})$, $h(r, t)$ is the hydraulic head at distance $\mathrm{r}$ and time $t(\mathrm{~m})$, and $h_{w}$ is the hydraulic head in the well (m). 
The method of determining the size of additional resistances used in this study was published by Agarwal et al. [16] in relation to the oil sector. This solution is derived from a drop in pressure across the impacted area surrounding the well, given an unsteady flow. Several assumptions have been made for modeling [34,36]:

- $\quad$ The aquifer is confined and has a seemingly infinite areal extent.

- $\quad$ The aquifer is homogeneous and isotropic and of uniform thickness over the area.

- The flow is horizontal.

- $\quad$ Prior to pumping, the piezometric surface is horizontal over the area.

- $\quad$ The pumping rate is constant throughout the pumping test.

- $\quad$ The well penetrates the entire thickness of the aquifer.

- $\quad$ The well has a finite volume, and the well storage coefficient is constant throughout the pumping test.

- $\quad$ Additional resistances in the well and its surroundings are non-zero.

For groundwater flow, in terms of dimensionless parameters, the well-known diffusivity equation in the radial coordinates has the form $[16,34,42,44]$

$$
\frac{\partial^{2} s_{D}}{\partial r_{D}^{2}}+\frac{1}{r_{D}} \frac{\partial s_{D}}{\partial r_{D}}=\frac{\partial s_{D}}{\partial t_{D}}
$$

Initial and boundary conditions:

At time $t=0$ and when applying the dimensionless parameters of Equations (6) to (8),

$$
s_{D}\left(r_{D}, t_{D}=0\right)=0 .
$$

In the case of dimensionless well drawdown

$$
s_{w D}\left(r_{D}=1, t_{D}=0\right)=0
$$

For $r_{D} \rightarrow \infty$, dimensionless drawdown is as follows:

$$
s_{D}\left(r_{D}, t_{D}\right)=0(14)
$$

The marginal condition for additional resistances in the well and its surroundings is as follows [14]:

$$
s_{w D}=s_{D}+\left(r_{D} \frac{\partial s_{D}}{\partial r_{D}}\right)_{r_{D}=1} W
$$

The outer condition for a pumped well when factoring in the impact of the well volume on the pumping test in relation to Equation (15) is (see [24])

$$
C_{D} \frac{\partial s_{D}}{\partial t_{D}}-\left(r_{D} \frac{\partial s_{D}}{\partial r_{D}}\right)_{r_{D}=1}=1
$$

Equation (11) is solved using a one-dimensional Laplace transform. The following type of transform function is used to convert the partial differential equation in dimensionless parameters into an ordinary differential equation [25]:

$$
F(p)=L(f(t))=\int_{0}^{\infty} f(t) e^{-p t} d t
$$

The transformed solution in the Laplace domain for dimensionless drawdown is

$$
\overline{s_{D}}=\frac{K_{0}\left(r_{D} p^{0.5}\right)}{p\left\{p^{0.5} K_{1}\left(p^{0.5}\right)+C_{D} p\left[K_{0}\left(p^{0.5}\right)+W p^{0.5} K_{1}\left(p^{0.5}\right)\right]\right\}}
$$


The transformed solution in the Laplace domain for dimensionless drawdown at a well (from Equations (16) and (18)) is

$$
\overline{s_{w D}}=\frac{K_{0}\left(p^{0.5}\right)-W p^{0.5} K_{1}\left(p^{0.5}\right)}{p\left[p^{0.5} K_{1}\left(p^{0.5}\right)+C_{D} p^{0.5}\left(K_{0}\left(p^{0.5}\right)+W p^{0.5} K_{1}\left(p^{0.5}\right)\right)\right]^{\prime}},
$$

where $p$ is the Laplace operator; $K_{0}$ and $K_{1}$ are the zero- and unit-order modified Bessel functions, respectively; $\overline{S_{W D}}$ is the dimensionless well drawdown in the Laplace domain; and $s_{W D}$ is obtained by Stehfest numerical inversion [25]:

$$
\begin{gathered}
s_{W D}\left(t_{D}\right)=\frac{\ln (2)}{t} \sum_{i=1}^{N} V_{i} \overline{s_{w D}}(p) \\
p=i \frac{\ln (2)}{t} \\
V_{i}=(-1)^{\frac{n}{2}+i} \sum_{k=\left[\frac{i+1}{2}\right]}^{\min \left(i, \frac{n}{2}\right)} \frac{k^{\frac{n}{2}}(2 k !)}{\left[\left(\frac{n}{2}-k\right) ! k !(k-1) !(i-k) !(2 k-i) !\right]}
\end{gathered}
$$

\section{Data}

The data used for the analysis come from Serbia. The parameters of the aquifer and the well can be seen in Tables 1 and 2. The parameters obtained from the pumping test already include the anisotropy and inhomogeneity of the aquifer. In addition, most of the aquifers can be considered uniform with constant thickness.

Table 1. Parameters of the aquifer.

\begin{tabular}{ccc}
\hline Name & $\begin{array}{c}\text { Transmissivity } \mathbf{T} \\
\left(\mathbf{m}^{\mathbf{2}} \mathbf{s}^{-\mathbf{1}}\right.\end{array}$ & $\begin{array}{c}\text { Storativity } \mathbf{S} \\
(-)\end{array}$ \\
\hline B1 & 0.00585 & 0.013 \\
B3 & 0.00385 & 0.0123 \\
B6 & 0.0036 & 0.00864 \\
\hline
\end{tabular}

Table 2. Parameters of the well.

\begin{tabular}{cccc}
\hline Name & $\begin{array}{c}\mathbf{r}_{\mathbf{W}} \\
(\mathbf{m})\end{array}$ & $\begin{array}{c}\text { Well Depth } \\
(\mathbf{m})\end{array}$ & $\begin{array}{c}\text { Well Storativity } \\
(-)\end{array}$ \\
\hline B1 & 0.149 & 87 & 996.6 \\
B3 & 0.1615 & 120 & 689.7 \\
B6 & 0.1615 & 110 & 2405.3 \\
\hline
\end{tabular}

These data are limited by several uncertainties, which may occur because of several reasons: (1) structural-technical, (2) methodological, and (3) hydrogeological.

1. In the first group especially, besides the construction design and use of material for collection wells, the type of connection and handling of pumping technology, including the drainage of water through the pipelines, one limiting factor is the initial phase of pumping, at which point the measurement can be affected by the dispersion of the moving elements of the submersible pumps. (This happens particularly in the case of high-capacity water supply wells in systems that are usually regulated by safety features, especially by frequency alternators.) As a result, there is a delay in reaching the originally set up pumping output. Another potential effect can be caused by the pressure resistance of the adjoining pipeline distribution system, including hydraulic shocks and the volume of the water in the discharge pipe (especially where non-return valves are absent).

2. Methodological causes are related to the choice of the duration of the hydrodynamic tests conducted, as well as to adjustments and interpretation of measurement data, 
which, in the case of horizontal inhomogeneity, tends to provide, with increasing time, increasing variation in the evaluation of hydraulic parameters.

3. Hydrogeological causes of limitations and uncertainties of hydraulic parameters are mainly related to the vertical inhomogeneity of the rock environment when, in permeable rocks, the water flow follows the principle of dual porosity, which means it has a strong tendency to flow through preferential channels. Aquifers are usually divided into several individual tributaries, and they can also have different levels of underground water; moreover, the vertical direction of the water flow may also change. Then, if, during the pumping test, the groundwater level falls below that of one of the tributaries and the level of the latter also rises above the level of the saturated water flow, significant changes in the dynamics of measured levels occur, which also contribute to uncertainties in the interpretation of the resulting data.

As far as the overall effects of the abovementioned limitations and uncertainties are concerned, the significance of errors of the sought-after parameters proportionally reflects the significance and size of the total input parameters.

\section{Results}

Software

Part of the process of developing the software was to analyze the limits of the computational method used. The analysis consists of two parts. The first part examines the accuracy of the sought parameters, depending on the pumping test duration, being $10 \%, 20 \%, 30 \%$, and up to $100 \%$ of the total duration. The obtained parameters are then compared with the value that most corresponds to reality. This cross-sectional value for individual runs of pumping tests was obtained by applying the computing method at the core of the software. All pumping tests were examined by the same computing method. Different values of the non-dimensional additional resistance and non-dimensional storativity of the drilling well were applied until a near $100 \%$ match in the runs of the simulated and real pumping tests occurred. This article presents the analysis of a single well before and after regeneration. This analysis represents the trend observed for all pumping tests analyzed. Figures 3 and 4 depict the percentage variance of well storage and additional resistances relative to optimal values. As is evident from Figures 3 and 4 , the variance in the case of the skin effect when using only $1 \%$ of the total pumping test data is around $30 \%$ from the optimal value. When using $3 \%$ of the data, the variance is less than $5 \%$. When using more than $5 \%$ of the data, highly accurate results are achieved that may be taken as authoritative. With increasing use of section data, the variance shows a slightly declining trend. With regard to the sought parameter of well storage (see Figures 3 and 4), using $0.5 \%$ of the data in both cases corresponds to a very small variance, not exceeding $2 \%$. The variance shows a clear increasing trend for data use of up to $6 \%$ and a declining trend thereafter. This is because well storage affects only the initial phase of the pumping test, in the order of minutes at most, but more likely seconds. This analysis indicates that it is expedient to use data covering $10 \%$ of the test for two reasons: (1) the time-consuming nature of the calculation process, which should be minimized to the greatest extent possible, and (2) the high accuracy of the resulting parameters already achieved at this stage. 


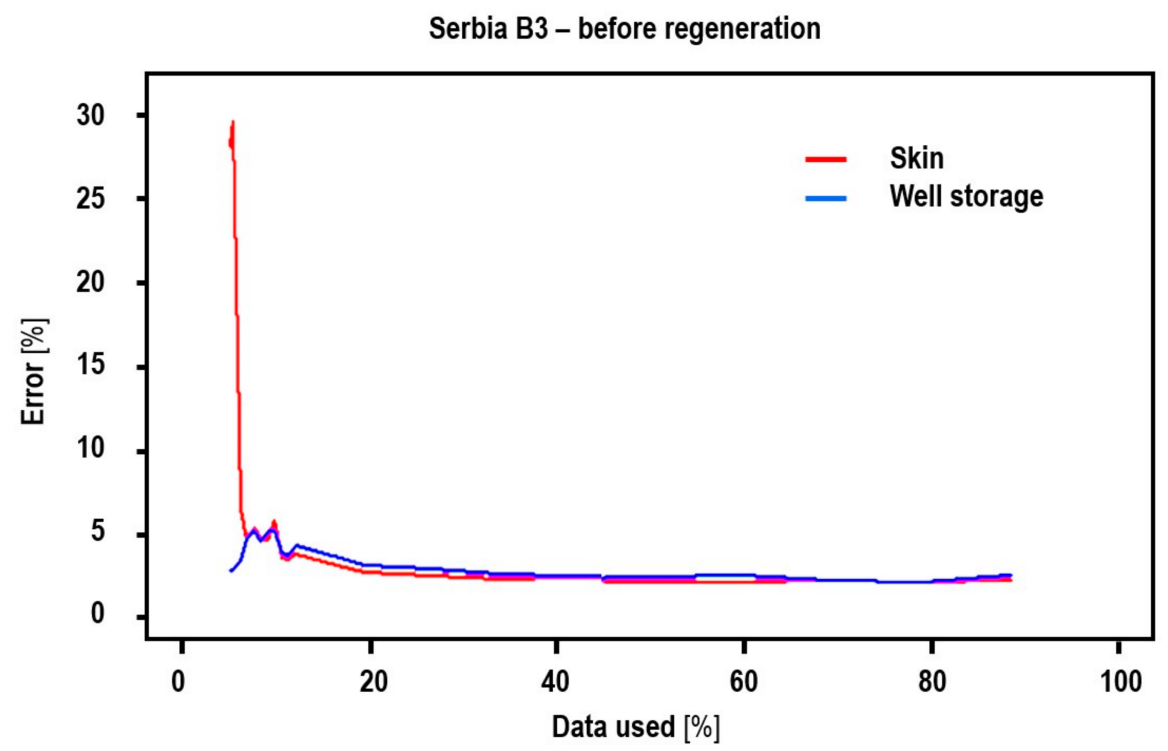

Figure 3. Plot depicting the percentage error for the skin effect and well storage parameters for the well Serbia B3 before regeneration dependent upon the percentage of data used from the pumping test.

Serbia B3 - after regeneration

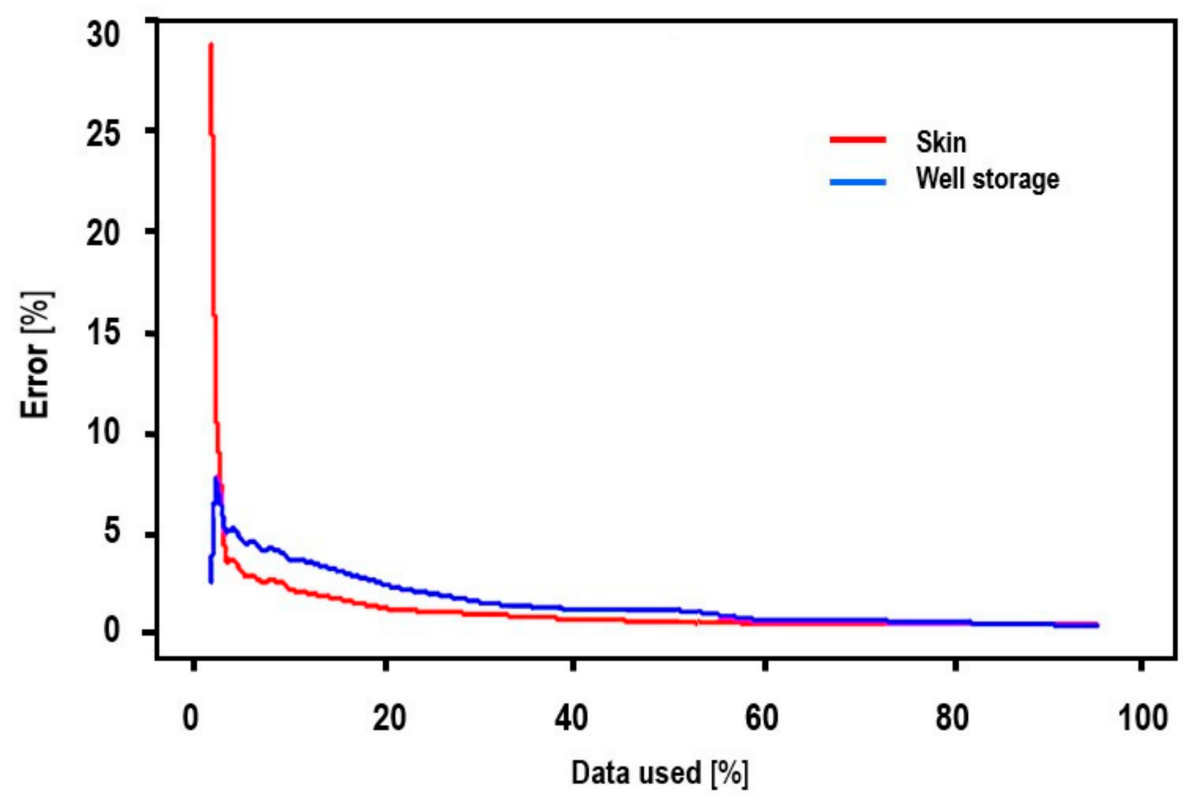

Figure 4. Plot depicting the percentage error for the skin effect and well storage parameters for the well Serbia B3 after regeneration dependent upon the percentage of data used from the pumping test.

The second part of the analysis examines the accuracy when using a combination of individual sections of the pumping test. This approach may be suitable when a measurement error or brief outage of the pump occurs during the pumping test or when a portion of data is missing. Figure 5 shows the division of the pumping test into individual sections. 


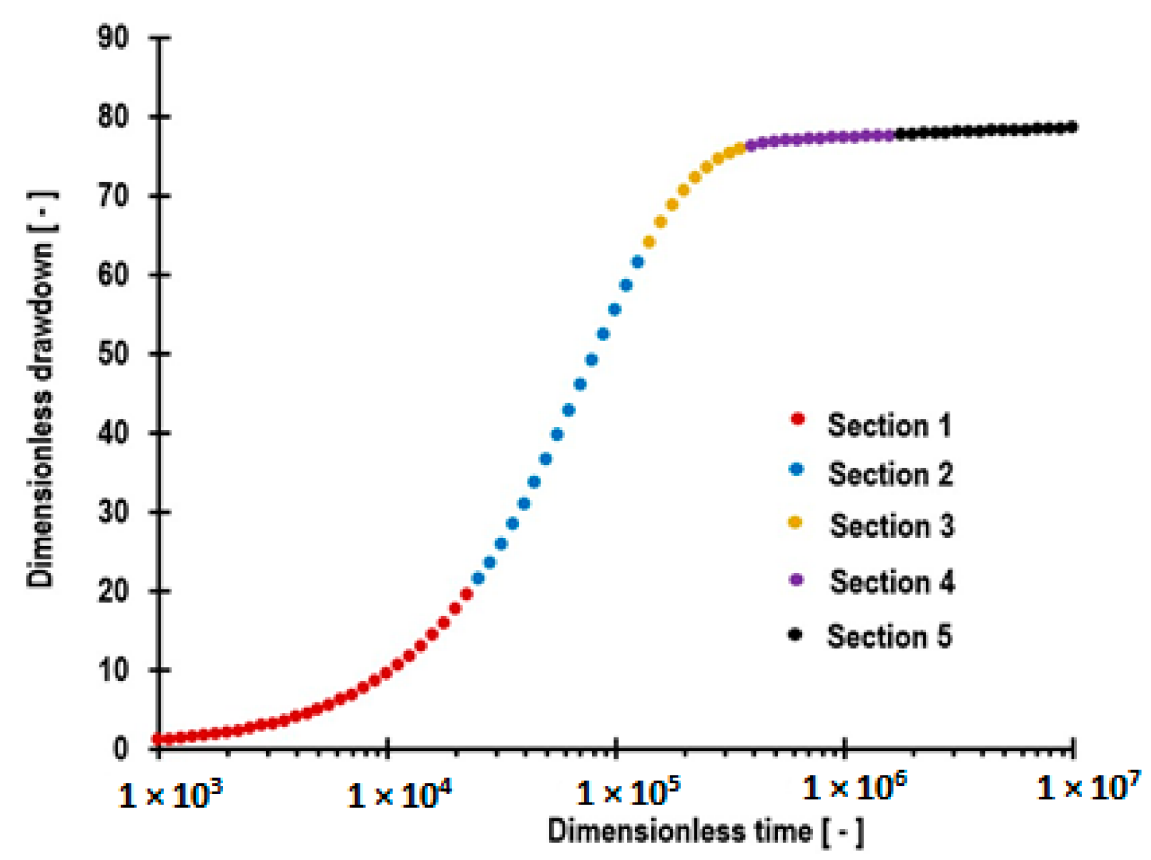

Figure 5. Plot showing division of the pumping test into individual sections.

All analyzed pumping tests were divided in a similar manner into sections, whose shapes were influenced by specific parameters (see Figure 1). A pumping test is divided into the initial section, the first straight section, the section between the first and second straight sections, the second straight section, and the final section. As stated above, the sought parameters of additional resistances and well storage are obtained using an optimization method of differential evolution, where it is necessary for the user to enter a range of values that he or she finds most likely to be optimal. This analysis was conducted both for the optimal limit (i.e., the limit at which the optimal values were found) and for the double limit. For example, if the optimal limit is in the range of 0 to 100 , then the double limit is in the range of 0 to 200. In the case of this optimization method, the range entered by the user is crucial for achieving accurate results. Figure 6 shows the additional parameter resistances evaluated. Again, in this case, the poorest estimate was given by the combination of the first and second sections. The combination of the first and fourth sections shows an overestimate, albeit only for the double limit. Once again, this trend was observed also in other analyzed wells, and the error for all combinations did not exceed $2 \%$. The main information obtained from this analysis is that all combinations of sections for both optimal and double limits give highly accurate values for the sought parameters. This is important in terms of practical use, when a situation may occur in which it is necessary to omit some sections of the pumping test. Figure 7 shows the evaluated parameter well storage for individual combinations of sections. The red horizontal dotted line indicates the optimal value. As the figure shows, the poorest estimate for the optimal and double limits was given by the combination of the first and second sections, followed by the combination of the third and fourth sections. Of course, the maximum error is up to $3 \%$. 


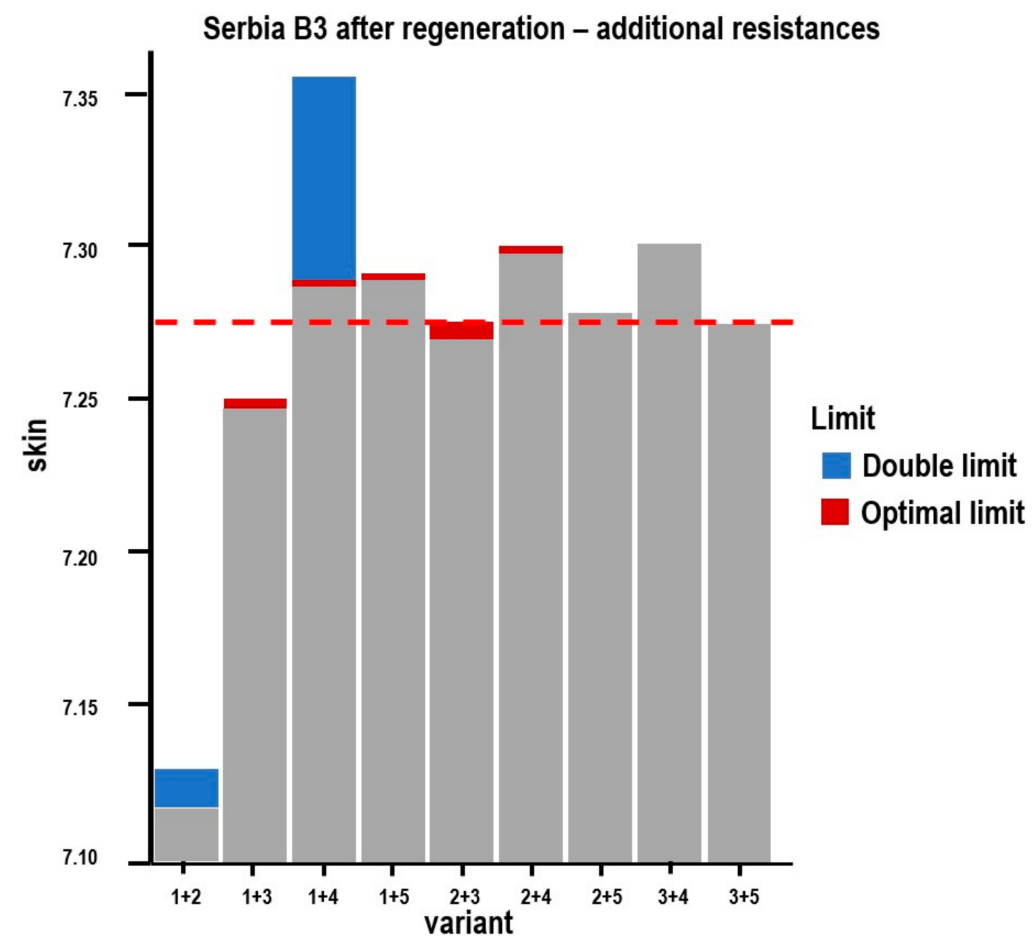

Figure 6. Resulting values of the parameter additional resistances.

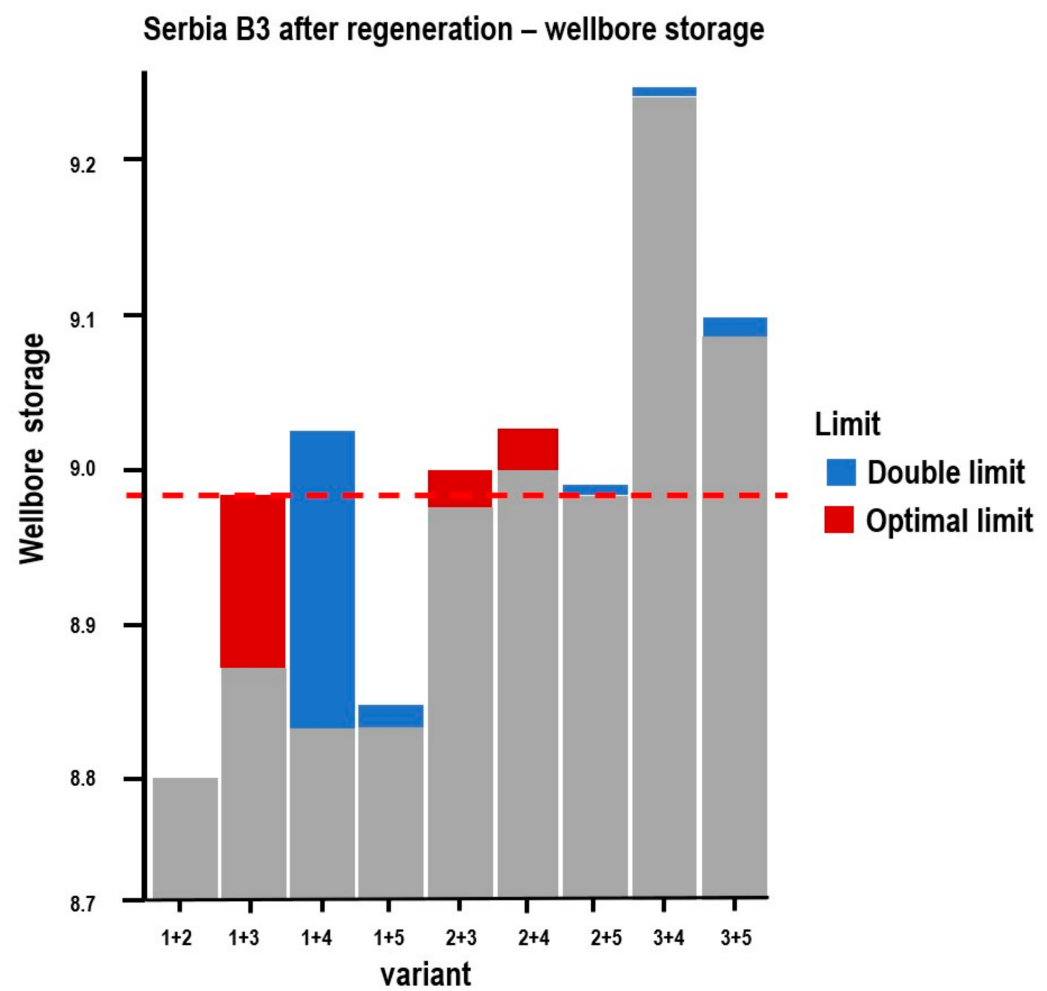

Figure 7. Resulting values of the parameter well storage, depending on the combination of sections used.

Now, we present a description of the software. A block diagram of the software is shown in Figure 8. This software primarily determines the parameters' additional resistances and well storage. It also evaluates an aquifer's hydraulic conductivity, the range of the cone of depression, and transmissivity. The user may also use the program to plot the results on a graph or to store them in a special format for use in another environment, such as the R programming language. However, all settings, including for data may also be 
opened directly in the software. The software also enables automatic generation of a final report, which may be partly modified according to the user's needs.

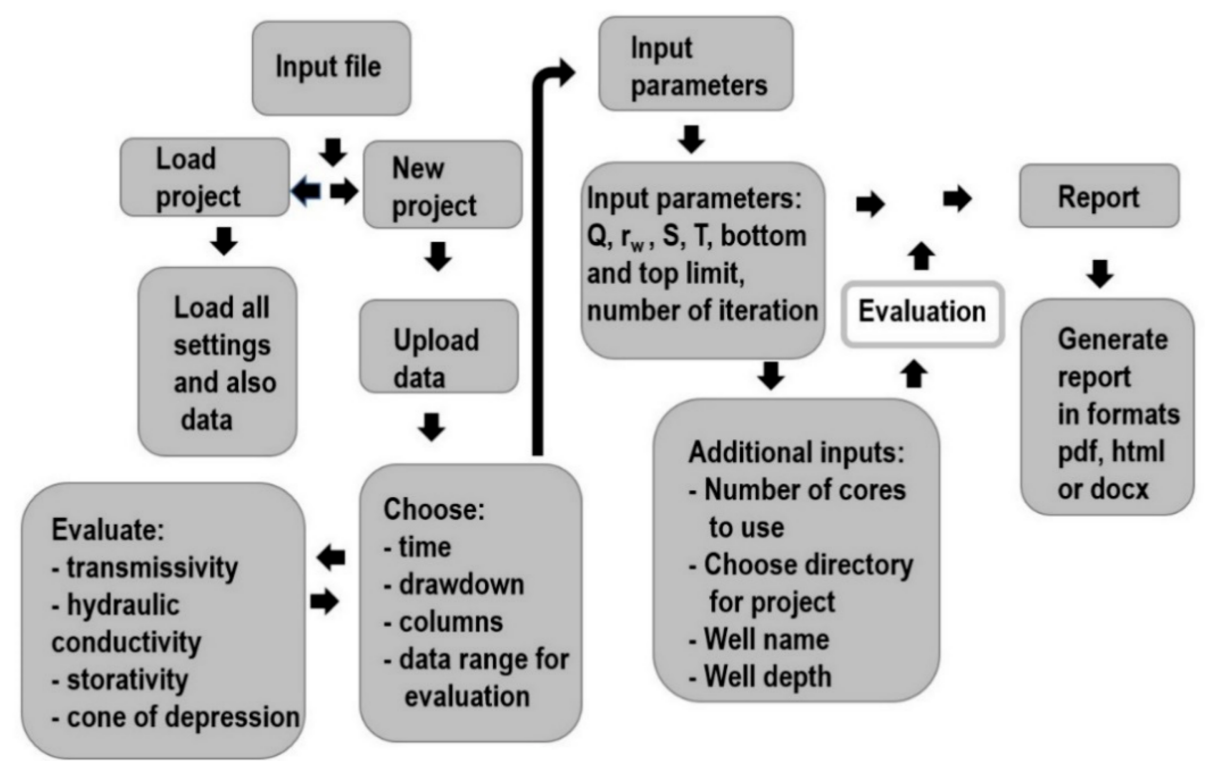

Figure 8. Software diagram.

Next, we describe the user interface. The software is divided into three main tabs: Input file, Input parameters, and Report. Each of these tabs comprises two to three levels. Below, we describe how to use the software. Start-up (see Figure 9) loads the introductory menu, where the user may select whether to start a new project or make changes to or continue a project already created. If the user chooses to work on a new project, he or she is prompted to upload a file containing the pumping test data. Files may be in txt or xlsx format. If a different file format is selected, the software shows a warning and takes no action. If an xlsx file is uploaded, the user must then select the respective sheet within which the data can be found. After uploading a file and, if necessary, selecting the appropriate worksheet, the program proceeds to the next tab: Input file.

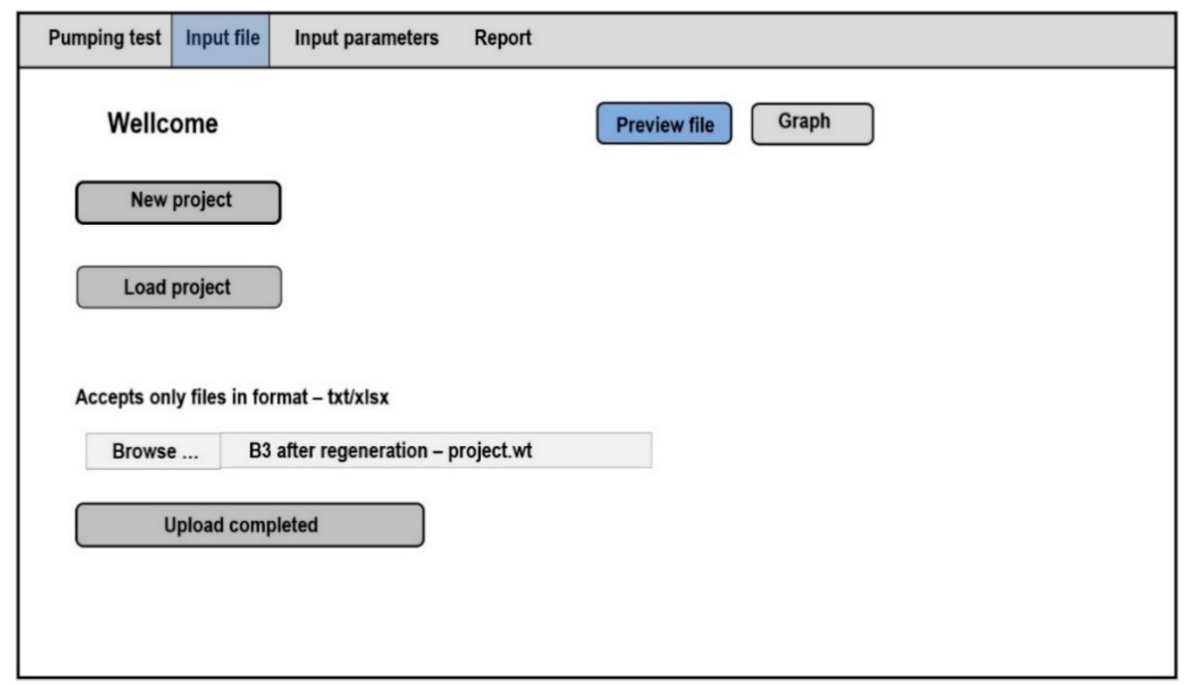

Figure 9. Start-up menu: illustrative image.

Now, the user selects how many rows to display from the uploaded file. The default setting is to display only 20 rows, mainly for reasons of computational demand. This tab also offers options for the choice of separators to divide individual columns. There are 
three options: Comma, Semicolon, and Table The final choice is the decimal separator: Comma or Period. The Preview file button to the right allows the user to inspect the data (see Figure 10). The user then proceeds to the next step by clicking Next. At this stage, the user must select the respective columns representing time and drawdown in the well. Here, the user may also choose any section of the data to be used in the calculations. The section can be selected by entering its beginning and end. Clicking the Graph button on the right displays a plot of the selected data (see Figure 11). The plot shows the section of data selected for calculation in red and the rest of the pumping test data in black.

\begin{tabular}{|c|c|c|c|c|c|}
\hline 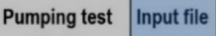 & Input parameters & Report & & & \\
\hline Display data & & Previev & & & \\
\hline$\square$ Head & & $t(s)$ & $s(m)$ & $t(s)$ & $s(m)$ \\
\hline$\nabla \quad$ All & & 0.00 & 0.00 & 13.00 & 1.25 \\
\hline & & 1.10 & 0.04 & 14.00 & 1.42 \\
\hline Separator & & 2.00 & 0.08 & 15.00 & 1.54 \\
\hline$\square$ Comma & & 3.00 & 0.10 & 16.00 & 1.68 \\
\hline 口 Semicolon & & 4.00 & 0.18 & 17.00 & 1.82 \\
\hline (D) Tab & & 5.00 & 0.27 & 18.00 & 1.94 \\
\hline & & 6.00 & 0.36 & 19.00 & 2.07 \\
\hline Decimal separator & & 7.00 & 0.48 & 20.00 & 2.12 \\
\hline 口 Comma & & 8.00 & 0.59 & & \\
\hline (1) Period & & $\begin{array}{l}9.00 \\
10.00\end{array}$ & $\begin{array}{l}0.71 \\
0.85\end{array}$ & & \\
\hline & & $\begin{array}{l}10.00 \\
11.00\end{array}$ & 0.97 & & \\
\hline \begin{tabular}{|l|} 
Previous \\
\end{tabular} & ext & 12.00 & 1.12 & & \\
\hline
\end{tabular}

Figure 10. Data display and choice of separator: illustrative image.

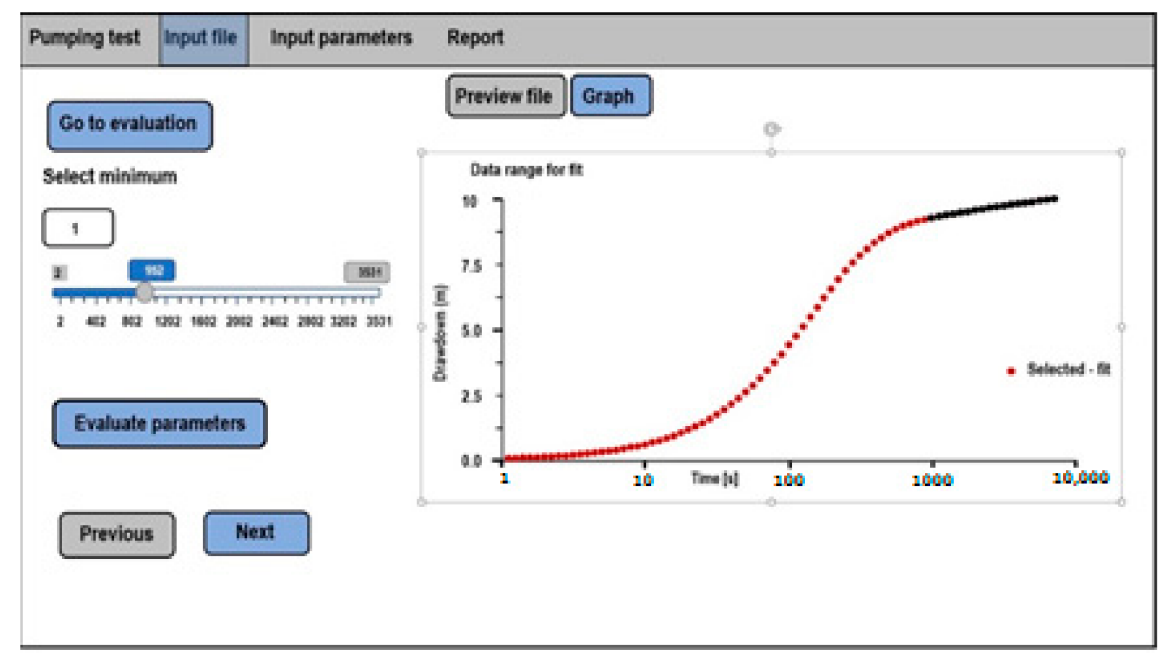

Figure 11. Checking the pumping test and choice of the data section for calculation: illustrative image.

As mentioned above, the software may also be used to evaluate an aquifer's transmissivity, hydraulic conductivity, and the range of the cone of depression. If the user wishes to evaluate one of these parameters, he or she must click the Evaluate parameters button, after which a menu of parameters appears. In the case of evaluating transmissivity, a plot is displayed, for which it is necessary to select the data found in the second straight section. Data selection is done as in the case of selecting data for calculations (see Figure 12). 


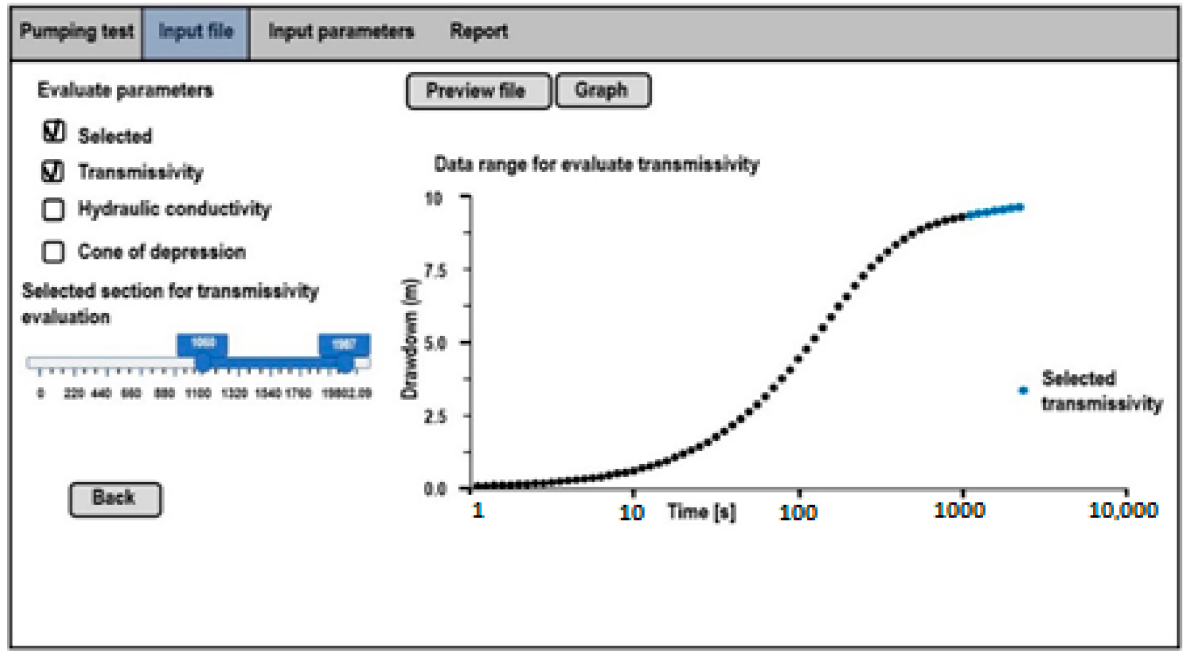

Figure 12. Data range for transmissivity evaluation: illustrative image.

In the case of evaluating the range of the cone of depression or hydraulic conductivity, the user must enter the aquifer thickness. The user may then proceed to the second tab: Input parameters. The first step in this tab is to enter the required parameters: the pumped amount, the well radius, storativity, and transmissivity. If these parameters are available in a file, the user may upload the file and display the data using the Preview file button, as in the case of uploading a file with pumping test data. The next step in this tab is to set the lower and upper limits between which the software will search for the optimal storativity and dimensionless additional resistance values. Before running the calculation, the user may also select the number of processor cores to use and whether to save the project. After completing the calculation, the user may inspect the resulting simulation by clicking the Graph button (see Figure 13).

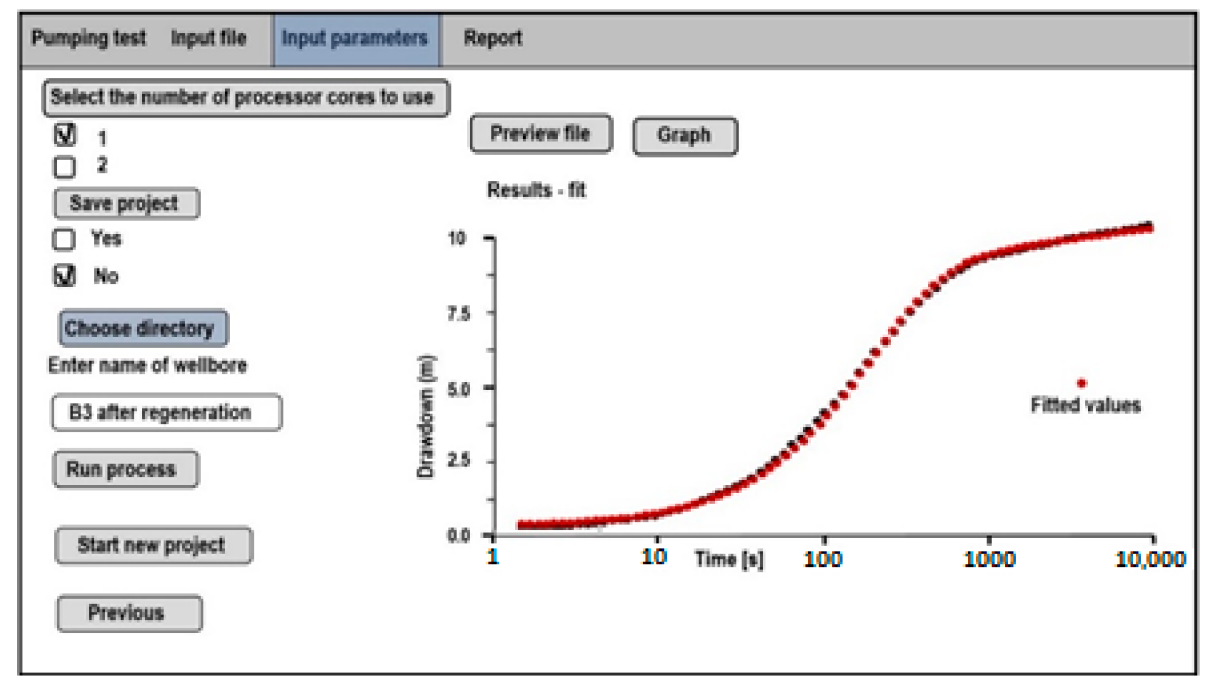

Figure 13. Plot of a real (black) vs. simulated (red) pumping test: illustrative image.

If the simulated pumping test mirrors the real test, this indicates that the calculated parameters are optimal. In the case of a bad fit, the user may select different lower and upper limits and repeat the calculation. As previously mentioned, the software also allows storage of the final report in pdf, html, or docx format. Clicking the Report tab loads a menu where the user can select the type of graph to be included in the final report (see Figure 14). Here, the user may also enter the well's location and depth. The final step is to select the format for the final report. 


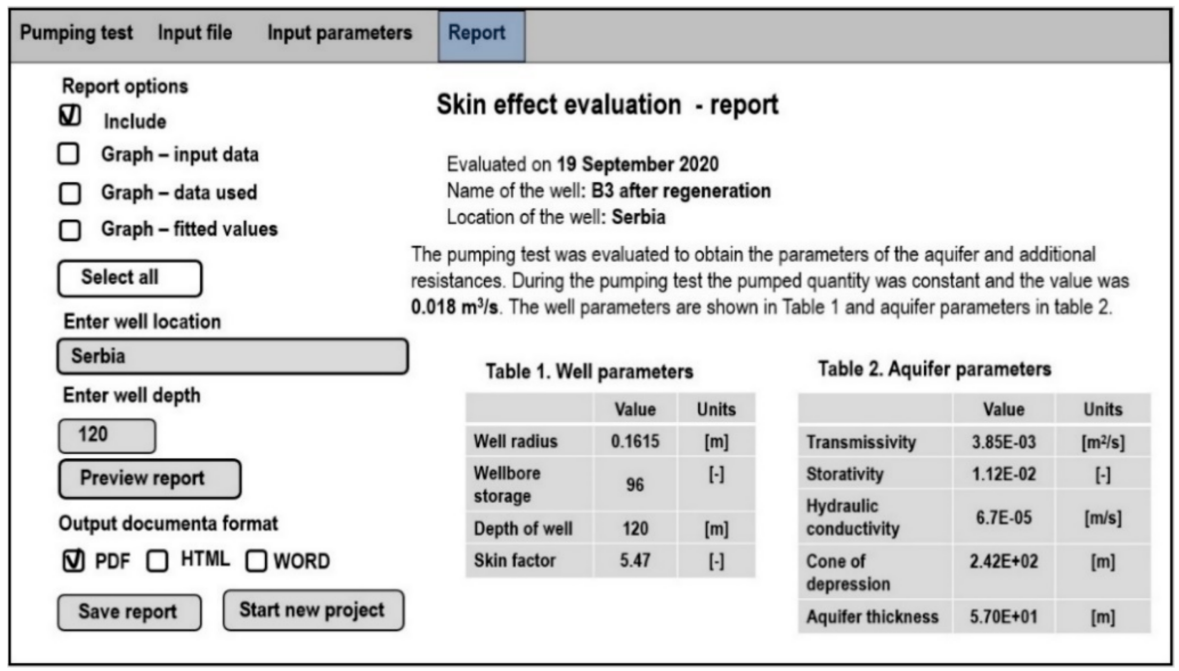

Figure 14. Output report: illustrative image.

\section{Discussion}

The created software was used to evaluate several real pumping tests, and the resulting additional resistance values were compared with those from another calculation method. The resulting skin effect values were compared with the solution presented by Equation (3).

As is evident from Tables 3 and 4, in most cases, the resulting values were nearly identical, differing in the vast majority of cases by only tenths. In the case of Obrtka O9B, the evaluated skin factor was higher (+2), representing a $27 \%$ divergence. The calculation stemming from Agarwal's solution requires a pair of initial parameters representing time and corresponding drawdown in the second straight section. For this reason, there exists a set of combinations that may be used in the calculation, thereby generating divergent results. For this calculation, it is, of course, necessary to have available pumping data up to the time when the inflow into the well approaches a steady flow. The software, on the other hand, can evaluate the skin effect with high accuracy, even when using a considerably shorter section of pumping test data. Highly accurate results may be achieved using around $5 \%$ of the total pumping test data. Well storage, as mentioned, impacts the initial phase of the pumping test on the order of seconds and, in a few cases, tens of seconds (depending on the well radius). Thanks to the calculation method used, it is possible to determine well storage even when using an early time section of the pumping test data that was not impacted by well storage. As found in the analysis of the limits of the calculation method used, accurate results for additional resistances and well storage are obtained when using any combination of pumping test sections. Therefore, this method is suitable for use with pumping tests in cases when, for example, there has been a pump outage or there are missing data in some sections of the test. 
Table 3. Resulting additional resistance values.

\begin{tabular}{|c|c|c|c|c|c|c|c|c|}
\hline Locality and Well Name & $\frac{\mathrm{Q}}{\left(\mathrm{m}^{3} \mathrm{~s}^{-1}\right)}$ & $\begin{array}{c}r_{W} \\
(\mathrm{~m})\end{array}$ & $\begin{array}{c}T \\
\left(m^{-2} s^{-1}\right)\end{array}$ & $\begin{array}{c}\text { S } \\
(-)\end{array}$ & $\begin{array}{c}C_{D} \\
(-)\end{array}$ & $\begin{array}{c}\text { W } \\
\text { Software }\end{array}$ & $\begin{array}{c}\text { W } \\
\text { Cooper-Jacob } \\
\text { Equation (3) }\end{array}$ & $\begin{array}{c}\text { Percentage } \\
\text { Divergence (\%) }\end{array}$ \\
\hline Serbia B-1 & 0.0102 & 0.1500 & 0.0058 & 0.0130 & 990 & 5.41 & 5.25 & 3 \\
\hline Serbia B-3 & 0.0180 & 0.1615 & 0.0026 & 0.0441 & 50.0 & 5.45 & 5.29 & 3 \\
\hline Serbia B-6 & 0.0118 & 0.0118 & 0.0036 & 0.0863 & 148 & 3.03 & 3.56 & 15 \\
\hline Serbia EB-1 & 0.0122 & 0.1615 & 0.003 & 0.0023 & 2360 & 4.84 & 4.74 & 2 \\
\hline Drnovec CV-2 & 0.0588 & 0.1625 & 0.00241 & 0.0011 & 900 & 1.01 & 0.95 & 6 \\
\hline Radouň RD-1 & 0.019 & 0.15 & 0.0098 & 0.00066 & 160 & 1.6 & 1.45 & 9.4 \\
\hline Radouň RD-2 & 0.142 & 0.15 & 0.00106 & 0.00018 & 180 & 2.66 & 2.68 & 1 \\
\hline Kolín KV-2 & 0.0022 & 0.17 & 0.0245 & 0.076 & 16 & 5.72 & 5.17 & 10 \\
\hline Kolín KV-9 & 0.00416 & 0.17 & 0.023 & 0.076 & 10 & 4.98 & 5.01 & 1 \\
\hline Obrtka O9A & 0.0026 & 0.186 & 0.0234 & 0.00038 & 5500 & 7.2 & 7.31 & 1.5 \\
\hline Obrtka O9B & 0.0097 & 0.125 & 0.00186 & 0.0419 & 160 & 7.21 & 5.23 & 27 \\
\hline
\end{tabular}

Table 4. Synthetic tests.

\begin{tabular}{cccccccccc}
\hline $\begin{array}{c}\text { Synthetic } \\
\text { Test }\end{array}$ & $\begin{array}{c}\mathbf{Q} \\
\left(\mathbf{m}^{\mathbf{3}} \mathbf{s}^{-\mathbf{1}}\right)\end{array}$ & $\begin{array}{c}\mathbf{r}_{\mathbf{W}} \\
\mathbf{( m )}\end{array}$ & $\begin{array}{c}\mathbf{T} \\
\left(\mathbf{m}^{-\mathbf{2}} \mathbf{s}^{-\mathbf{1}}\right)\end{array}$ & $\begin{array}{c}\mathbf{S} \\
\mathbf{( - )}\end{array}$ & $\begin{array}{c}\mathbf{C}_{\mathbf{D}} \\
\mathbf{( - )}\end{array}$ & $\begin{array}{c}\mathbf{W} \\
\mathbf{( - )}\end{array}$ & $\begin{array}{c}\mathbf{W} \\
\text { Software }\end{array}$ & $\begin{array}{c}\mathbf{W} \\
\text { Cooper-Jacob } \\
\text { Equation (3) }\end{array}$ & $\begin{array}{c}\text { Percentage } \\
\text { Divergence (\%) }\end{array}$ \\
\hline Test 1 & 0.005 & 0.20 & 0.0120 & 0.010 & 100 & 10 & 9.998 & 9.97 & 0.24 \\
Test 2 & 0.003 & 0.25 & 0.0015 & 0.002 & 100,000 & 20 & 20.0003 & 19.99 & 0.0017 \\
Test 3 & 0.012 & 0.40 & 0.0030 & 0.0025 & 100,000 & 50 & 50.007 & 49.99 & 0.0141 \\
\hline
\end{tabular}

\section{Conclusions}

The result of this work is a functional piece of software that considerably reduces the time demand when determining the magnitude of additional resistances and well storage. One of the advantages of this software is that it is available for free upon request to the authors (ficaj@fzp.czu.cz). It can also be downloaded from the following website: https:/ / github.com/Ficaj/Wtest (accessed on 23 March 2021). Compared to most other similar software programs (AQtesolv, AquiferTest, MLU), which might take many years to develop, this one can be handled easily and almost intuitively. As a result, there is no need for time-consuming training. Most other software programs also lack the unique computing method used here. As mentioned above, the key benefit of this method is that it is based on the initial straight-line tract. Thanks to this method, dozens of minutes can be saved in real-life tests. Moreover, other benefits could be added, such as reducing the time needed for evaluation so that it is not much longer than one minute, as well as the preparation of a (predefined) report. This software is capable, among other things, of evaluating the following parameters: an aquifer's transmissivity, storativity, the range of the cone of depression, and hydraulic conductivity.

Author Contributions: Conceptualization, D.K., P.P. and V.F.; methodology, P.P.; software, V.F.; validation, D.K. and V.F.; investigation, P.P.; resources, D.K.; writing-original draft preparation, V.F., D.K. and P.P.; writing-review and editing, P.P., V.F. and D.K.; project administration, P.P. All authors have read and agreed to the published version of the manuscript.

Software: The software available for free upon request to the authors at ficaj@fzp.czu.cz.

Funding: This research was funded by the Technology Agency of the Czech Republic (grant number TH02030421) under the project titled ULTRA—Technology for Pumping Well Rehabilitation Based on Ultrasound Emission.

Institutional Review Board Statement: Not applicable.

Informed Consent Statement: Not applicable. 
Data Availability Statement: Data supporting reported results can be found at https:/ /github.com/ Ficaj/Wtest.

Conflicts of Interest: The authors declare no conflict of interest.

\section{References}

1. Theis, C.V. The relation between the lowering of the piezometric surface and the rate and duration of discharge of a well using ground-water storage. Trans. Am. Geophys. Union 1935, 16, 519-524. [CrossRef]

2. Carslaw, H.S. Introduction to the Mathematical Theory of the Conduction of Heat in Solids; Macmillan and, Co.: London, UK, 1921; p. 286.

3. Cooper, H.H.; Jacob, C.E. A generalized graphical method for evaluating formation constants and summarizing well-field history. Trans. Am. Geophys. Union 1946, 27, 526-534. [CrossRef]

4. Van Everdingen, A.F. The skin effect and its influence on the productive capacity of a well. J. Pet. Technol. 1953, 5, 171-176. [CrossRef]

5. Hurst, W. Establishment of skin effect and its impediment to fluid flow into a well bore. Pet. Eng. 1953, 25, B6-B16.

6. Hawkins, M.F., Jr. A note on the skin effect. Trans. Am. Inst. Min. Metall. Eng. 1956, 8, 356-357. [CrossRef]

7. Papadopulos, I.S.; Cooper, H.H. Drawdown in a well of large diameter. Water Resour. Res. 1967, 3, 241-244. [CrossRef]

8. Ramey, H.J.; Agarwal, R.G. Annulus unloading rates as influenced by wellbore storage and skin effect. Soc. Pet. Eng. J. 1972, 12, 453-462. [CrossRef]

9. Bourdet, D. Well test analysis: The use of advanced interpretation models. Handb. Pet. Explor. Prod. 2002, 3, 1-426. [CrossRef]

10. Batu, V. Aquifer Hydraulics: A Comprehensive Guide to Hydrogeologic Data Analysis; John Wiley $\alpha$ Sons: New York, NY, USA, 1998; p. 727. ISBN 0-471-18502-7.

11. Kucuk, F.; Brigham, W.E. Transient flow in elliptical systems. Soc. Pet. Eng. J. 1979, 19, 401-410. [CrossRef]

12. Mathias, S.A.; Butler, A.P. Flow to a finite diameter well in a horizontally anisotropic aquifer with well storage. Water Resour. Res. 2007, 43, 1-6. [CrossRef]

13. Yang, S.Y.; Yeh, H.D. Laplace-domain solutions for radial two-zone flow equations under the conditions of constant-head and partially penetrating well. J. Hydraul. Eng. ASCE 2005, 131, 209-216. [CrossRef]

14. Chen, C.S.; Chang, C.C. Theoretical evaluation of non-uniform skin effect on aquifer response under constant rate pumping. J. Hydrol. 2006, 317, 190-201. [CrossRef]

15. Yeh, H.D.; Yang, S.Y.; Peng, H.Y. A new closed-form solution for a radial two-layer drawdown equation for groundwater under constant-flux pumping in a finite-radius well. Adv. Water Resour. 2003, 26, 747-757. [CrossRef]

16. Agarwal, R.G.; Al-Hussainy, R.; Ramey, H.J. An investigation of well storage and skin effect in unsteady liquid flow: I. Analytical treatment. Soc. Pet. Eng. J. 1970, 10, 279-291. [CrossRef]

17. Wattenbarger, R.A.; Ramey, H.J. An investigation of well storage and skin effect in unsteady liquid flow: II. Finite difference treatment. Soc. Pet. Eng. J. 1970, 10, 291-297. [CrossRef]

18. Kasenow, M. Determination of Hydraulic conductivity from Grain Size Analysis; Water Resources Publications LLC.: Carlton, CO, USA, 2010; p. 196. ISBN 978-1-887201-58-2.

19. Gringarten, A.C.; Bourdet, D.P.; Landel, P.A.; Kniazeff, V.J. A comparison between different skin and well storage type-curves for early-time transient analysis. Soc. Pet. Eng. Spe. Ann. Techn. C Exh. 1979, 1-16. [CrossRef]

20. Earlougher, R.C., Jr. Advances in well test analysis. In Monograph Series-Society of Petroleum Engineers of AIME; SPE International: Dallas, TX, USA, 1977; p. 264.

21. Earlougher, R.C., Jr.; Kersch, K.H. Analysis of short-time transient test data by type- curve matching. J. Pet. Technol. 1974, 26, 793-800. [CrossRef]

22. Novakowski, K.S. A Composite analytical model for analysis of pumping tests af fected by well bore storage and finite thickness skin. Water Resour. Res. 1989, 25, 1937-1946. [CrossRef]

23. Chu, W.C.; Garcia-Rivera, J.; Raghavan, R. Analysis of interference test data influenced by well storage and skin at the flowing well. J. Pet. Technol. 1980, 32, 623-630. [CrossRef]

24. Van Everdingen, A.F.; Hurst, W. The application of the Laplace transformation to flow problems in reservoirs. J. Pet. Technol. 1949, 1, 305-324. [CrossRef]

25. Watlton, W.C. Aquifer Test Modeling, 1st ed.; CRC Press: Boca Ralton, FL, USA, 2007; p. 240. ISBN 978-1-4200-4292-4.

26. Stehfest, H. Algorithm368: NumericalinversionofLaplacetransforms. Commun. ACM 1970, 13, 47-49. [CrossRef]

27. Al-Ajmi, N.M.; Ahmadi, M.; Ozkan, E.; Kazemi, H. Numerical Inversion of Laplace Transforms in the Solution of Transient Flow Problems With Discontinuities. In Proceedings of the SPE Annual Technical Conference and Exhibition, Denver, CO, USA, 21-24 September 2008. [CrossRef]

28. Yang, S.Y.; Yeh, H.D. Radial groundwater flow to a finite diameter well in a leaky confined aquifer with a finite-thickness skin. Hydrol. Process. 2009, 23, 3382-3390. [CrossRef]

29. Hall, P.; Chen, J. Water Well and Aquifer Test Analysis; Water Resources Publication, LLC.: Carlton, CO, USA, 1996 ; p. 409. ISBN 0-918334-93-4.

30. Pasandi, M.; Samani, N.; Barry, D.A. Effect of well and finite thickness skin on flow to a partially penetrating well in a phreatic aquifer. Adv. Water Resour. 2008, 31, 383-398. [CrossRef] 
31. Payne, F.; Quinnan, J.; Potter, S. Remediation Hydraulics; CRC Press: London, UK, 2008; p. 432. ISBN 978-0849372490.

32. Hiscock, K.M.; Bense, V.F. Hydrogeology Principles and Practice; Wiley-Blackwell: River St, Hoboken, NJ, USA, $2014 ;$ p. 544. ISBN 978-0-470-65662-4.

33. Chen, C.; Lan, C. A simple data analysis method for a pumping test with skin and well storage effect. Terr. Atmos. Ocean. Sci. 2009, 20, 557-562. [CrossRef]

34. Kruseman, G.P.; de Ridder, N.A. Analysis and Evaluation of Pumping Test Data, 2nd ed.; IILRI: Wageningen, The Netherlands, 2008; pp. 1-372.

35. Wen, Z.; Huang, H.G.; Zhan, H.B. Non-Darcian flow in a single confined vertical fracture toward a well. J. Hydrol. 2006, 330, 698-708. [CrossRef]

36. Barua, G.; Bora, S.N. Hydraulics of a partially penetrating well with skin zone in a confined aquifer. Adv. Water Resour. 2010, 33, 1575-1587. [CrossRef]

37. Kahuda, D.; Pech, P. A new method for evaluation of well rehabilitation from the early-portion of the pumping test. Water 2020, 12, 744. [CrossRef]

38. Dastkhan, Z.; Zolalemin, A.; Razminia, K.; Parvizi, H. Minimization and Removal of Well Storage Effect by Direct Deconvolution of Well Test Data; SPE Reservoir Characterisation and Simulation C onference and Exhibition: Abu Dhabi, United Arab Emirates, 2015. [CrossRef]

39. Sousa, E.P.; Barreto, A.B.; Peres, A.M. Analytical Treatment of Pressure-Transient Solutions for Gas Wells With Well Storage and Skin Effects by the Green's Functions Method. SPE J. 2016, 21, 1858-1869. [CrossRef]

40. Fan, Z.; Rarashar, R. Transient flow to a finite-radius well with well storage and skin effect in a poroelastic confined aquifer. Adv. Water Resour. 2020, 142, 103604. [CrossRef]

41. Holub, J.; Pech, P.; Kuraz, M.; Maca, P.; Kahuda, D. Evaluation of a pumping test with skin effect and well storage on a confined aquifer in the Bela Crkva, Serbia. Int. J. Water 2019, 13, 1-11. [CrossRef]

42. Liu, P.C.; Li, W.H.; Xia, J.; Jiao, Y.W.; Bie, A.F. Derivation and application of mathematical model for well test analysis with variable skin factor in hydrocarbon reservoirs. AIP Adv. 2016, 6. [CrossRef]

43. Sethi, R. A dual-well step drawdown method for the estimation of linear and non-linear flow Parameters and well skin factor in confined aquifer systems. J. Hydrol. 2011, 400, 187-194. [CrossRef]

44. Mashayekhizadeh, M.D.; Ghazanfari, M.H. The application of numerical Laplace in version methods for type curve development in well testing: A comparative study. Pet. Sci. Technol. 2011, 29, 695-707. [CrossRef] 